\title{
Performance Study on China's ST Companies_-Based on Factor Analysis Combined with Contribution Rate of Variance
}

\author{
Sen Wang \\ Jinan University, Zhuhai 519070, Guangdong, China \\ Shanxi University of Finance and Economics, Taiyuan 030006, Shanxi, China \\ E-mail: twilson@jnu.edu.cn \\ Qi Wang \\ Department of Finance, Jinan University, Zhuhai 519070, Guangdong, China
}

\begin{abstract}
The listed companies will be specially treated when their business performance is bad or there are serious accidents, which is a rule to reveal the investment risk of stock market. So it is very important to study the performance of listed companies under special treatment (ST companies) for the development of stock market in China. We choose 50 companies as the samples in the ST plate of 2006 in accordance with the industry categories and scale, and use Factor Analysis to study the integrated performance of the sample companies during 2005-2007. Our research conclusion shows that (1) the integrated performance of companies is the fundamental factor to determine whether it will be specially treated or not. (2) The performance of ST companies in china during 2005-2007 shows the upward trend, but their positive effects have gradually been decreased over time. (3) The profitability and debt paying ability of ST companies play very important roles. (4)The effective approaches of improving ST are corporate restructuring, asset stripping and debt restructuring.
\end{abstract}

Keywords: Special Treatment Companies (ST), Factor Analysis, Contribution Rate of Variance, Corporate Restructuring, Performance Evaluation

\section{Preface}

Since ST was implemented in 1998, it has promoted a healthy development of China's stock market. The main situations in recent years are that new added ST (including * ST) companies and ST-removed companies both decline, which never happened in the past. One hand, there were only 9 new ST companies in 2007, while only 5 in 2008; there were 72 warning treatment (* ST) stocks in 2007, while just 33 in 2008. We can see from the decreasing quantity, specially treated companies had made every effort to perform well in order to avoid entering delisting warning period. On the other hand, seen from ST-removed companies, the quantity tends to decrease, which indicates the performance improvement of ST plate was declining.

By the end of April of 2009, there had been 172 stocks in China's ST plate, among which 99 stocks were specially treated (ST) and 73 stocks were warned of delisting (* ST). Concerned with industrial distribution, most of ST companies belong to C manufacturers, accounting for 59.3\%, followed by G information technology companies and $\mathrm{M}$ integration, accounting for $11.04 \%$ and $8.13 \%$ respectively. This situation indicates, as China's leading manufacturers, listed manufacturing companies must attract attentions of relevant departments on their running conditions. China still has many problems to be solved in order to keep its position as the world's manufacturing powerhouse.

Although the government and academia are happy on the decreasing quantity of ST companies, it is still very important to deeply study the countermeasures to ST companies for furthering China's capital market, seen from two aspects: ST-removed companies are shrinking; ST companies are mostly manufacturers.

\section{Literature Review}

Since 1930s Factor Analysis has been widely applied in computer, medicine, agriculture, economics and management, and so on. As early as 1932, American Fitzpatrick managed to find crisis signal by comparative analysis on financial indicators of crisis companies and healthy companies. Afterward, following Fitzpatrick's idea, the researches on crisis companies has reached very high level in the world. Some main researches in recent years are as follows. Eivind Bernhardson (2001) thought in the Revealed Difference Model, information 
asymmetry of financial conditions is the reason of company crisis. Stephen A. Hillegeist and Elizabeth (2002) appraised Altman's (1968) Z index model and Ohlson's (1980) 0 index model, furthermore, utilized discrete risk model to test the financial data of sample companies. They thought it is defective for traditional accounting to depend on bankruptcy risk and the establishment of corporate capital operation indicators can more scientifically evaluate unsound companies. Stanislava M. Nikolova (2003) claimed loan loss and debt risk are the main reasons causing problems by forecasting the variable of the estimated value of the volatility of risky assets assessment. Darrell Duffie and Ke Wang (2004) found out most of unsound companies in American industrial mechanism departments attributed to unlimited corporate expansion. Charitou A., Neophytou E. and Charalambous C. (2004) studied the influence of changing cash flow on financial distress by corporate forecasting model, which contributes to proper making financial indicator factors to forecast the probability of corporate failure.

Since 1980s China has started to apply Factor Analysis to solve practical problems in many fields. However, Shanghai and Shenzhen Stock Exchange Launched ST system in 1998. Then the empirical study on judging and forecasting financial crisis of Chinese listed companies referring to international mode has emerged in China. Chen Jing (1999) chose 27 ST companies and 27 non-ST companies to make univariate analysis and multivariate linear judging analysis. She found the evaluation and forecasting model established by 6 indicators, i.e. debt ratio, return on equity (ROE), liquidity ratio, working capital, total assets and total asset turnover, has better forecast effect during the first three years of corporate ST period. Wu Shinong and Lu Xianyi (2001) chose 70 companies with financial distress and 70 companies with normal finance as samples. Firstly, they applied profile analysis and univariate judging analysis to study 21 financial indicators' differences of the two types of companies annually during five years before financial distress. Finally they chose 6 forecasting indicators and utilized Fisher linear judging analysis, multiple linear regression analysis and Logistic regression analysis to establish three models of forecasting financial distress respectively. The research result shows the information timeliness of 16 financial indicators is comparatively strong one or two years before financial distress, in which the discriminate success rate of return on net assets is higher. The three models can all make comparatively accurate forecast before financial distress, whose error rate is less than $28 \%$ four years before financial distress. In terms of the same information set, Logistic forecast model has the lowest error rate which is only $6.47 \%$ one year before financial distress. Chen Shou and Zhang Sha (2004) adopted excess earnings method and the financial index method to make an empirical research on the restructuring performance of ST companies in China's stock market. The cumulative average abnormal returns (CAAR) of ST companies three years after restructuring is revealed to be positive. The research by financial index method showed the performance of ST companies in the restructuring year had no obvious improvement, but was markedly better after one year, while declined in the subsequent years. Ma Ruowei (2006) applied Rough Set Theory (RS) selected forecast model indicator system objectively, with ST companies listed by abnormal financial situation as the mark of defining listed companies' financial distress. Artificial Neural Networks (ANN) was utilized to search the best model for forecasting the financial distress of China's listed companies by public financial data. The result indicated 18 financial indicators, including return on total assets and indicators of cash flow, can apparently distinguish companies with financial difficulties and healthy companies. Industrial type and assets scale are rather essential for listed companies to forecast financial distress. The neural network model by applying ANN has strong and stable forecasting capacity. Yang Zhi and He Yong (2006) studied the main economic factors restricting China's ST and *ST companies. They studied 137 ST and *ST companies of Shanghai and Shenzhen stock markets in the end of 2004 by Factor Analysis method. The conclusion shows the essential factor of restricting the development of China's ST and *ST companies is heavy debt burden. Poor daily working performance is another important factor. While corporate development capacity and assets management efficiency are comparatively subordinate.

As a significant topic, the performance of ST companies has been studied by many scholars. And the empirical research methods are also discovered in many aspects. The main research evolvement is as follows. Firstly, scholars reviewed the financial indicators of ST companies to study their long-term performance through fixed ratio analysis and chain analysis, which is actually a kind of descriptive statistical method. This research result shows that these ST companies meet the requirement of removing ST through restructuring from earning ability perspective, but actually they are quite lack of capital after restructuring and removing ST, without sustainable development capacity. So their performance hasn't been furthered from long-term perspective. Secondly, some scholars adopted the second relative efficiency method to study ST performance. This method can predict the prospects of the ST stock. Meanwhile, this evaluation method also removed the differences in each company based on the impact of the objective. It is suitable for detailed analysis of each company. Thirdly, Factor Analysis is most used in corporate performance research due to its high efficiency and practicality. Most of scholars used one-year data to do research when adopting Factor Analysis method to study ST performance, and 
then find the focus affecting performance based on the main factors obtained from the method.

To sum up, non-Chinese scholars focused on model establishment on the topics related to research, while Chinese scholars followed them but just focused on forecasting crisis. So the future evolutionary trend after crisis is still an uncultivated virgin. We considered each aspect in this paper and adopted Factor Analysis method on the main body of the model finally. The utilization of the methods has breakthrough on the basis of previous ones. There are three aspects of innovation. Firstly, we establish analysis on dynamic time period so as to make a judgment on the whole development trend of ST plate. Secondly, we extend Factor Analysis method and use variance contribution rate and factor score to co-found an integrated model of performance scores. Thirdly, we comprehensively utilize several-year data for more comprehensive judgments in the Factor Analysis process.

\section{Sample Selection}

In the previous research, most of relevant issues are based on one-year analysis. However, we think for the entire evaluation of ST plate performance, the result on one-year financial data is obviously not complete enough. Based on the general standard of economic research, we shall study on ST plate performance in recent three years. Considering the timely changes of granting and removing ST of ST shares, we shall select ST plate companies among share A in 2006. The research objects of this paper are ST sample companies from 2005 to 2007.

The stock pool has 132 shares, among which we select 50, i.e. $37.88 \%$ as research sample. These 132 shares are distributed in 11 industries. According to the industrial proportion of the 132 companies, we select the industrial distribution of samples. Considering the typical significance of research result, we shall select more influential sample companies in scale factor of the industry as research objects.

\section{Performance Analysis on Sample Companies}

It is noteworthy that the promoting role of ST system on corporate performance improvement of ST plate is not as of great progress in a whole as the first years of the implementation of the system, but it occurs that more obvious differentiation, which indicates the role of ST system decreases over time. The situation of China's ST companies in recent years tends to polarization. Firstly, the ST top 10 companies, in addition to ST China Agriculture, S*ST Tianhai, ST Kelon and ST Kelon, have been successfully removed ST. Secondly, the ST bottom 10 companies, except Park City Shares, Dongan Panthers, Pearl River Holding, are still specially treated, 9 of which are warned of delisting. It can be seen, top-ranking companies tend to be removed of ST, but lag companies are getting worse.

We can clearly see from the final rank statistic by integrated model of performance scores, special treatment companies (capped with ST) or delisting warning companies (capped with *ST) don't mean a financial indicator is wrong or something is out of way, but the whole decline of integrated performance causes a certain phenomenon meets the requirement of ST or *ST rules. Therefore, if a company would like to remove ST, it can't depend on superficial or unilateral improvement of one or several financial indicators, but manages to promote corporate integrated performance. As long as integrated performance is promoted, they can solve the problem of removing ST essentially. Through empirical research, corporate integrated performance is the basic factor determining ST or non-ST.

Table 2 and Figure 1 definitely indicate the selected sample of ST plate in 2006 has upward tendency on integrated performance from 2005 to 2007. It is easy to make a conclusion based on the randomicity and universality that the integrated performance of ST plate goes up. Through empirical research, we conclude the implementation of ST system has a positive effect on improving corporate situation.

We can see from Figure 1, the performance improvement of each company during 2005-2006 is obviously better than that during 2006-2007. The data in this paper is from ST or *ST companies in 2006, who were specially treated just because of bad performance in 2005. When just being capped with ST or again, each company pays high attention to performance improvement, and starts to make every active effort to improve corporate situation. Some companies a little relax in 2007 because they effectively avoid delisting threat owing to performance improvement in 2006. So the performance improvement in this period obviously decline. Therefore, the implementation of ST system has strong effect on corporate performance from short-term perspective, while decreasing influential effect in long term.

For the analysis on indicator structure of ST companies, the determination on factor analysis of one certain year is not enough. So we combine obtained factor extraction and explanative results on three-year factor analysis to analyze the integrated performance of ST companies. Through analyzing three-factor extraction and table explanation, we can classify and explain common factors of each year respectively, and obtain the following 
table.

Through the above conclusion and summary, we obtain an integrated common factor explanation. The first common factor is determined by return on assets and earnings per share, which represents corporate profitability. The second common factor is determined by asset-liability ratio and current Ratio, which represents corporate solvency. The third common factor is determined by return on equity and net assets per share, which represents corporate ability of return on equity. The fourth common factor is determined by main business revenue growth rate and net profit growth rate, which represents corporate ability to grow. The fifth common factor is determined by inventory turnover rate and total asset turnover, which represents corporate operating capacity.

Combining sample factor characteristic root and variance contribution table we can see, these main factors have less and less contribution to corporate integrated performance. The first and the second common factors has almost accounted for $50 \%$ of contribution. Therefore, when entirely promoting integrated performance, a company needs to emphasize on profitability and solvency. On condition of normal profit and safe running, they can promote other abilities simultaneously. Thus Principal contradiction is grasped in order to achieve a multiplier effect.

The research indicates ST companies mostly adopt corporate restructuring in order to get improvement in short period. China's ST companies usually adopt the forms of asset replacement, asset sale and transfer, and debt restructuring to restructure a company so as to improve corporate entire situation. Among our sample companies, top ten companies in continuous three years removed ST by means of these restructuring forms. 12 companies make debt restructuring, 14 companies sell and transfer asset, and 6 companies replace asset. Seen from the data, many companies take more than one forms to make corporate restructuring. Zhongjiang Real Estate, whose integrated performance score ranks first in 2006, and Ziyi Stock, top 1 of that in 2007, both adopt the three forms to make restructuring during this period and achieve very good effect.

If ST companies want to get rid of distress, they have to make asset restructuring in time which is a very effective method. However, we think when restructuring asset, ST companies must consider corporate capital operating strategy for long term, and can't take these actions blindly just because of facing delisting. The research shows those companies who restructure asset in a hurry have declining performance in long term.

\section{Research Conclusion}

In any capital market there are always quite many listed companies get involved into distress due to a variety of reasons. In China, if the performance of listed companies' declines continuously or some big problems emerges, they will be given special treatment, i.e. capped with ST, which is a measurement of revealing investment risks based on the real situation of capital market. Theoretically speaking, ST bulletin means listed companies have serious financial problems or operating problems. When realizing it, investors must sell stocks in the market, so ST companies declare restructuring. If investors' expectation on restructuring is successful, the market will have a positive response. Thus, the share price of ST companies must change more than the market. Therefore, some stakeholders (such as investors or loaners) usually will take some methods to judge or predict the possibility of these companies' distress in order to avoid bigger loss. Listed companies will also apply certain measurements to get released from operating difficulty, especially asset restructuring. Empirical research is helpful to understand the behavior of participators in the market, to test the implementation effect of policies, to make investment decision for investors, and to establish foundation for listed companies' decision-making and for more proper regulations making of management departments. So empirical research is very significant for ST companies to evaluate performance.

We apply Factor Analysis method to study the integrated performance of 50 sample companies among ST plate from 2005 to 2007, and achieve four important conclusions. Firstly, the quantitative statistic analysis on combining several-year integrated performance ranking and removing ST situation of 50 companies, we find out corporate integrated performance is the essential factor of determining its ST status or not. Secondly, through comparing three-year total performance score and the changing speed, we claim the corporate performance on China's ST plate has an upward tendency during research period, which further indicates the implementation of ST system has a positive promoting effect on the whole situation of China's listed companies, but the effect is declining over time. Thirdly, through a comprehensive analysis on three-year factor loading matrix after model's rotating, in the process of ST companies' promoting performance in order to remove ST, profitability and solvency play almost 50\% role, so companies should strengthen these two aspects when making strategy and policies. Finally, by comparing good and poor companies, as well as the practical analysis on ST-removed companies, we see the most effective and fastest methods to remove ST are corporate restructuring and share distribution reform. The most corporate restructuring forms taken by China's successful ST-removed companies 
are asset replacement, asset sale and transfer, and debt restructuring.

\section{References}

Charitou A., Neophytou E., and Charalambous C. (2004). Predicting Corporate Failure: Empirical Evidence for UK. European Accounting Review. 13(3). pp465-497.

Darrell Duffie and Ke Wang. (2004). Multi - Period Corporate Failure Prediction with Stochastic Covariates. The National Bureau of Economics Research. 2004 Report. No.12. pp126-132.

Eivind Bernhardson. (2001). A Model for Bankruptcy Prediction. Norges Bank. Working Paper. No.9. pp101-110.

Stanislava M. Nikolova. (2003). The Informational Content and Accuracy of Implied Asset Volatility as a Measure of Total Firm Risk. University of Florida. Working Paper. No.8, pp33-42.

Stephen A. Hillegeist and Elizabeth. (2002). Assessing the probability of Bankruptcy. Harvard University. No.11, pp33-41.

Table 1. Industrial Distribution and Proportion of ST Plate Sample Companies in 2006

\begin{tabular}{|c|c|c|c|c|}
\hline $\begin{array}{l}\text { Code of } \\
\text { Industry }\end{array}$ & Name of Industry & $\begin{array}{l}\text { Quantity of } \\
\text { Industries }\end{array}$ & Percentage & Quantity of Samples \\
\hline $\mathrm{A}$ & $\begin{array}{l}\text { Agriculture, forestry, animal } \\
\text { husbandry, fishery }\end{array}$ & 6 & $4.55 \%$ & 2 \\
\hline $\mathrm{B}$ & Extractive Industry & 1 & $0.76 \%$ & 0 \\
\hline $\mathrm{C}$ & Manufacturing & 72 & $54.55 \%$ & 29 \\
\hline $\mathrm{E}$ & Building industry & 1 & $0.76 \%$ & 0 \\
\hline $\mathrm{F}$ & Transportation, warehousing & 3 & $2.27 \%$ & 1 \\
\hline G & IT Industry & 13 & $9.85 \%$ & 5 \\
\hline $\mathrm{H}$ & Wholesale and retail trade & 10 & $7.58 \%$ & 4 \\
\hline $\mathrm{J}$ & Real Estate & 14 & $10.61 \%$ & 6 \\
\hline $\mathrm{K}$ & Social Services & 1 & $0.76 \%$ & 0 \\
\hline $\mathrm{L}$ & $\begin{array}{l}\text { Communication and Cultural } \\
\text { Industries }\end{array}$ & 2 & $1.52 \%$ & 0 \\
\hline M & Miscellaneous & 9 & $6.82 \%$ & 3 \\
\hline
\end{tabular}

Data Source: Reith database information

Table 2. Integrated Performance Comparison of ST Sample Companies from 2005 to 2006

\begin{tabular}{c|c|c}
\hline Year & Total Score & Average Score \\
\hline 2005 & $-1.3935033424 \mathrm{E}-05$ & $-2.7870066849 \mathrm{E}-07$ \\
\hline 2006 & $1.223960228 \mathrm{E}-05$ & $2.4479204561 \mathrm{E}-07$ \\
\hline 2007 & $1.5007466529 \mathrm{E}-05$ & $3.0014933057 \mathrm{E}-07$ \\
\hline
\end{tabular}

Table 2 shows the integrated performance of ST companies goes up from negative score to positive one. 
Table 3. Table Explanation on Common Factors of ST Sample Data from 2005 to 2007

\begin{tabular}{|c|c|c|c|}
\hline Component & 2005 & 2006 & 2007 \\
\hline $\begin{array}{l}\text { The first common } \\
\text { factor }\end{array}$ & $\begin{array}{l}\text { Asset-liability ratio } \\
\text { Current Ratio } \\
\text { Net assets per share }\end{array}$ & $\begin{array}{l}\text { Return on assets } \\
\text { Earnings per share }\end{array}$ & $\begin{array}{c}\text { Return on assets } \\
\text { Net profit growth rate } \\
\text { Earnings per share }\end{array}$ \\
\hline $\begin{array}{l}\text { The second } \\
\text { common factor }\end{array}$ & $\begin{array}{l}\text { Return on assets } \\
\text { Earnings per share }\end{array}$ & $\begin{array}{c}\text { Return on equity } \\
\text { Inventory turnover rate }\end{array}$ & $\begin{array}{l}\text { Asset-liability ratio } \\
\text { Net assets per share } \\
\text { Current Ratio }\end{array}$ \\
\hline $\begin{array}{l}\text { The third common } \\
\text { factor }\end{array}$ & $\begin{array}{c}\text { Return on equity } \\
\text { Main business revenue } \\
\text { growth rate }\end{array}$ & $\begin{array}{l}\text { Asset-liability ratio } \\
\text { Net assets per share }\end{array}$ & $\begin{array}{c}\text { Return on equity } \\
\text { Total assets turnover }\end{array}$ \\
\hline $\begin{array}{l}\text { The fourth } \\
\text { common factor }\end{array}$ & Net profit growth rate & $\begin{array}{c}\text { Current Ratio } \\
\text { Main business revenue } \\
\text { growth rate }\end{array}$ & Inventory turnover rate \\
\hline $\begin{array}{l}\text { The fifth common } \\
\text { factor }\end{array}$ & $\begin{array}{c}\text { Inventory turnover rate } \\
\text { Total asset turnover }\end{array}$ & $\begin{array}{l}\text { Total asset turnover } \\
\text { Net profit growth rate }\end{array}$ & $\begin{array}{l}\text { Main business revenue } \\
\text { growth rate }\end{array}$ \\
\hline
\end{tabular}

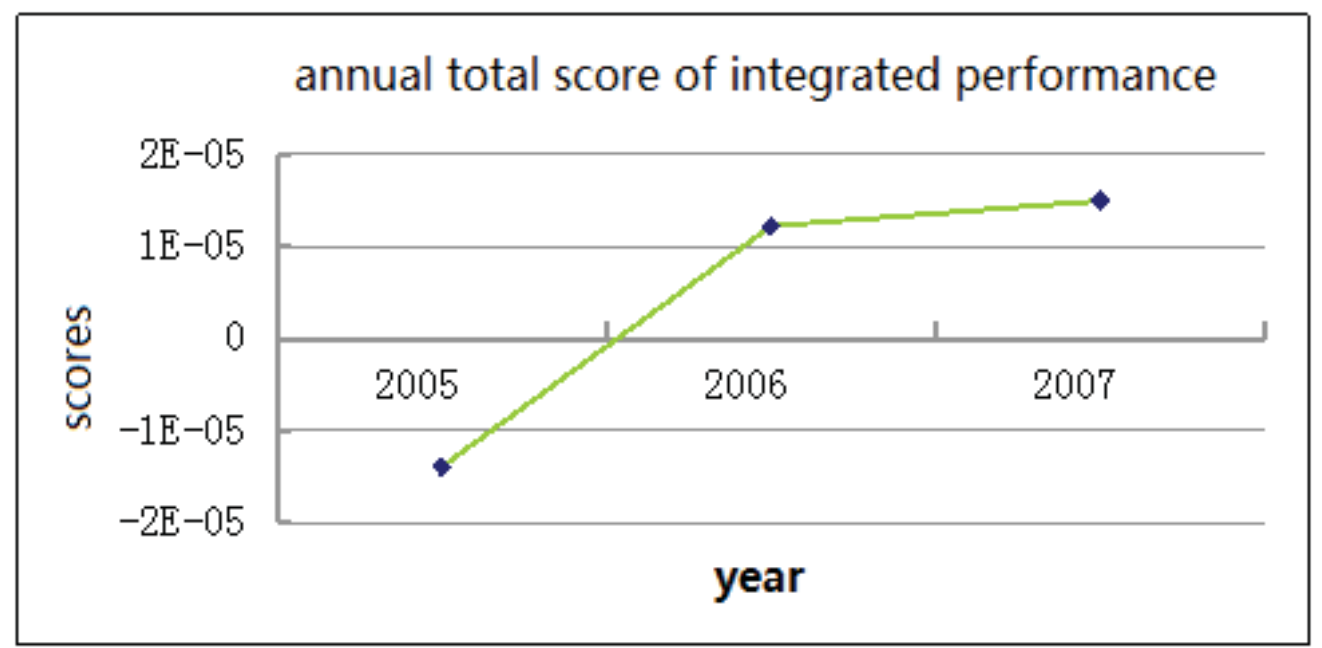

Figure 1. Total Score Trend of Integrated Performance of ST companies from 2005 to 2007 